\title{
DEBATING IGBO CONVERSION TO CHRIS- TIANITY: A CRITICAL INDIGENOUS VIEW
}

\author{
F. Hale ${ }^{1}$
}

\begin{abstract}
Since the 1970s the dynamics of conversion have been a focal point of research with regard to the impact of Christianity on traditional African societies. Much of the scholarly debate about the matter has concentrated on West Africa. Such academic authorities as Elizabeth Isichei, Robin Horton, and Caroline Ifeka-Moller provided different theories about the relative importance of various factors. Within the genre of the novel, West African writers like the Ibgos Chinua Achebe, John Munonye, and T. Obinkaram added their voices to the debate through their fictional reconstructions of the confrontation of missionary Christianity and traditional cultures. That of Onuora Nzekwu is explored in this article.
\end{abstract}

\section{DISPUTING THE FACTORS UNDERLYING THE IGBO RELIGIOUS METAMORPHOSIS}

The conversion of much of the expansive and internally diverse Igbo tribe in southern and south-eastern Nigeria to Christianity during the first few decades of the twentieth century after stiffly resisting the intrusion of missionaries before 1900 is one of many dramatic chapters in the history of the church in Africa. Indeed, the rate of conversion during a thirty-year period after 1900 is especially remarkable. As one historian of Christianity in Igboland has pointed out, fewer than 1000 Igbos may have converted during the latter half of the nineteenth century, but the census of 1931 indicated that in a total population of 3172789 Igbos no fewer than 347427 (ca. 11 per cent) identified themselves as Christians. Of the latter, the 94049 Catholics constituted a plurality of 27 per cent. $^{2}$

To be sure, some critics have contended that little depth of commitment to Christian doctrines accompanied this breadth of nominal change and membership in various mission-sponsored churches. They have also underscored their perception that traditional Igbo religious beliefs and practices remained strong in the ranks of the converted. Perhaps no

1 Prof. F. Hale, Dept. of English, University of Stellenbosch.

2 Elizabeth Isichei, A bistory of the Igbo people (London: Macmillan Press, 1976), pp. $165-166$. 
observer put it more succinctly than Onuora Nzekwu (b. 1928), whose novels of the 1960s made him one of the principal founders of postcolonial Nigerian literature. In his debut work of 1961, Wand of noble wood, Nzekwu voices his perceptions of the survival of traditional religion through an urbanised Igbo:

Go among the grown-ups who profess Christianity. The moment they can afford it they become polygamists and take ozo and other traditional titles. When they think it will do them good they consult fortune-tellers, make charms and wear them, and do a thousand and one other things which to their tens of African priests, who themselves mimic their white brother clerics, are purely "idolatrous and un-Christian". ${ }^{3}$

Other internal observers of Igbo life have dissented. Catholic novelist T. Obinkaram Echewa (b. 1940) has not veiled the fact that traditional beliefs and practices remained strong among rural converts to Christianity, but he has also pointed out that if measured by such indexes as attendance at Mass during the 1940s, large numbers of Igbos in his home area evinced great loyalty to the church. Reflecting on the entrenchment of Catholicism while he was growing up during the 1940s and 1950s, he has declared that "Catholic missions around Aba were generally very successful". Echewa's memory of the popularity of worship seems particularly acute:

I can remember that at Christ the King Church in Aba Sunday Mass was every hour on the hour from 5 a.m. until noon, and if you didn't arrive half an hour ahead of time to stand in line, you probably would not get in! ${ }^{4}$

In any case, missiologists, historians, and other scholars have long debated the relative importance of various factors which brought about the acceptance of Christianity. They have variously attributed it to inter alia a general desire on the part of the Igbos to cope with rapidly cultural change by appropriating at least some of the ways of their colonisers and capitulation to the material inveiglements of missionaries. Such explanations tend to beg the question of why missions were more successful amongst the Igbos than elsewhere.

3 Onuora Nzekwu, Wand of noble wood (London: Heinemann Educational Books, 1961), p. 76.

4 Frederick Hale private archives, T. Obinkaram Echewa files, T. Obinkaram Echewa (West Chester, Pennsylvania) to Professor F.A. Hale, 5 January 1996. 
One of the first scholars in Nigeria to attempt an explanation of the rapid conversion of so many of her ethnic fellows after 1900 was the historian Elizabeth Isichei. In her analysis of "The Growth of Christianity in Igboland" in her magisterial A bistory of the Igbo people, this New Zealander who was married to an Igbo took a multicausal approach to the general phenomenon. Isichei found in educational endeavours "the key factor" which brought about this change and placed this into the context of British imperial expansion into Igbo country. The literacy gained through attendance at mission schools gave participants a great social and economic advantage, because both the colonial administration and the schools themselves provided opportunities for remunerative employment. She explained,

The same emphasis on competitive achievement which had led the Igbo to struggle to accumulate the wealth to take a title, or to grow sufficiently numerous and excellent yams for a yam title, was easily transposed to education.

Apart from mission schools, she pointed in general terms to the work of medical missions, the improvement of communications, and urbanisation in loosening individuals' bonds to local religious practices as significant catalysts in easing the transition from tribal religion to Christianity. ${ }^{5}$

During the 1970s both Isichei and other scholars of religion debated the reasons why some Igbos converted to Christianity while others did not. Isichei asserted cautiously that "Igbo responses were largely conditioned by sociological factors". She did not deny that religious conversion was also an "emotional or spiritual reality" but assumed that as an historian she was empirically equipped to deal only with external determinants in analysing it. Isichei pointed out inter alia that the nineteenth and early twentieth centuries were an "age of anxiety" in Igboland owing to the intrusion of British culture and eventual conquest and asserted that in the resulting cauldron of social and cultural instability

very few men considered becoming Christians who were happily integrated in their society unless they felt that society to be threatened.

Consequently, missionaries

5 Isichei, A bistory of the Igbo people, pp. 167-169. 
drew their converts mainly from the rejects of Igbo society - those like slaves, or accused witches, who had no prospect of happiness in Igbo society and therefore nothing to lose by attaching themselves to another one. ${ }^{6}$

Isichei did not take upon herself the unenviable task of adducing evidence to substantiate these generalisations.

Professor Robin Horton, a philosopher at the University of Ife, countered Isichei with weapons from the arsenal of his own discipline. Decrying the domination of anthropological methodology in the field of religious studies, he declared that

a number of philosophers and philosophically minded social scientists have recently been calling for a return to the intellectualist approach which takes systems of traditional religious belief at their face value - i.e. as theoretical systems intended for the explanation, prediction, and control of space-time events.

Venturing a step further, Horton insisted provocatively that "intellectualism is in fact the only real starter in this field," particularly with regard to "studies of religious variation and change". He did not directly address the mass conversion of Igbos, choosing instead to rely heavily on J.D.Y. Peel's recent study of Aladura: a religious movement among the Yoruba of western Nigeria for his principal example of an African group who supposedly demonstrated his theory. ${ }^{7}$ In brief, Horton believed that all people are "shaken and discomfited when confronted with the bearers of alien belief-systems", a generalisation he thought particularly operative in colonised Africa. Christian missionaries, despite what Horton questionably regarded as a profound trend towards otherworldliness as opposed to a dual this- and otherworldliness during the past three centuries, brought to African peoples a religion which was both transcendent in its understanding of ultimate realities and concerned with the here and now. This struck a chord with the cosmology of Africans before the onset of evangelism, as "most African traditional religion does in fact have a dual nature"; i.e. its gods are "theoretical entities" and, in tandem with religious rituals, to venerate them is "to apply theory to the control of the world", but at

6 Elizabeth Isichei, "Seven varieties of ambiguity: some patterns of Igbo response to Christian Missions", Journal of Religion in Africa (1970), p. 209.

7 London: Oxford University Press for International African Institute, 1968. 
the same time "the gods are people, and their rituals an extension to the field of purely human social relationships". Horton argued that

if the missionaries had come in with a straight other-worldly creed, the Yoruba and many other African peoples would have rejected them.

Instead, they proclaimed to colonised nations "the promise of a new source of strength which would enable people to live in and cope with a new world". 8

Caroline Ifeka-Moller, an Africanist at the University of Birmingham, challenged Horton's theory as inoperable with regard to the Igbo during the years 1921-1966. She pointed out that he had postulated a unitary concept of African belief in divinity. This, however, hardly fitted Igbos' perceptions of the gods, which, as ethnographers and others had pointed out since early in the twentieth century, varied widely from one region to another with some Igbos not recognising a supreme god while others believed in one that they variously regarded as male or female. Ifeka-Moller also thought the intellectualist approach was suspect because it failed to take into consideration the geographical variation in rates of conversion to Christianity. The census of 1953, taken after two generations of ambitious missionary endeavours amongst the Igbos, indicated that in the province of Onitsha only 26 per cent of the population was classified as Christian, whereas in southerly Calabar province, where there was much greater imperialist economic activity, this figure had climbed to 77 per cent. Ifeka-Moller argued cogently that

conversion to mission Christianity in eastern Nigeria was most in evidence throughout our period in and around certain communities of the oil-palm belt. Villages which experienced intensive change went over rapidly, and in large numbers, to the mission churches and then to the Aladuras. Mass conversion was a consequence of these social changes: incorporation into the new world economy, the imposition of new political roles under the colonial system, and a growing realization among the inhabitants of these communities that they had failed to obtain the rewards promised by acceptance of these radical changes. Christianity promised a new kind of power, the power of the white man, which people could use to discover the secret of his technological superiority. ${ }^{\text {? }}$

8 Robin Horton, “African conversion”, Africa, 41(2) (April 1971), pp. 94-97, 107.

9 Caroline Ifeka-Moller, "White power: social-structural factors in conversion to Christianity, Eastern Nigeria, 1921-1966”, Canadian Journal of African Studies, 8(1) (1974), pp. 56-61. 
Other scholars, both in Nigeria and overseas, added their voices to the debate during the next two decades. E.A. Ayandele, a Baptist historian at the University of Ibadan, for example, wrote in 1973 that after the expansion of British imperialism at the turn of the century the "blissful insularity" of Igbo culture ended abruptly. The might of colonialism was immeasurably more apparent than were means of stopping either it or the waves of Anglican, Roman Catholic, and other missionaries who followed it its wake. Ayandele did not compromise his metaphors in describing the religio-cultural impact of missionary Christianity:

With the systematic destruction of the Long Juju by the British invaders between 1900 and 1902[,] the Bible rolled through Igboland like a Juggernaut, crushing the gods to atoms.

Indigenous means seemed entirely ineffective in checking this assault, so

the Igboman in the first decade [of the twentieth century] was in no way disposed to invoke the already discredited traditional religion to halt the white man's religious intrusion into his world and invasion of his being.

Instead, Ayandele asserted,

he anxiously sought the aid of the missionary whom he looked to for enactment of expected miracles - the establishment of the school and transformation of his children away from the indigenous world into "book" people, the emerging new élite leaders who in the colonial setting were to share authority in Church and State.

The desire for education naturally played a key rôle in this acculturation, which Ayandele saw as a vital component of Igbo self-initiative. $\mathrm{He}$ also regarded medical missions as particularly significant in effecting conversions. ${ }^{10}$

The eminent Igbo church historian Ogbu U. Kalu swam against a swift current of what he termed "nationalist historiography" in 1990 by stressing the primacy of the white missionary factor in the conversion of the Igbos. Bemoaning a perceived tendency of African historians to "suppress awkward facts", Kalu argued that, beginning in the

10 E.A. Ayandele, "The collapse of 'pagandom' in Igboland", Journal of the Historical Society of Nigeria, 7(1) (December 1973), pp. 125-139. 
1950 s and especially in the wake of independence in the 1960s, Nigerian and other scholars elsewhere on the continent had overplayed their hands in seeking to reverse the previous domination of "missionary historiography" (i.e. that written by missionaries and their sponsors) with its emphasis on the importance of foreign, and usually European, agents in the successful evangelisation of Igboland early in the twentieth century. Essential pillars of this new nationalist school were, first, an emphasis on the rôle of indigenous evangelists and catechists, and, secondly, a depiction of foreign missionaries as agents of imperialism whose versions of Christianity had pernicious effects on African culture. As a corollary to the second emphasis, some African historians had glorified indigenes who had resisted the intrusion of missionary Christianity. Kalu contended that, in general, those missions which had the largest number of and best equipped white missionaries had been the most effective in converting Igbos to the Christian faith. He enumerated such factors as fascination with the exotic (i.e. white people and their ways), the inveiglements of material goods, missionary ties to colonial governments, popular Igbo demands for mission schools at which they could learn English, and local distrust of black missionary personnel as particularly significant dimensions of this. ${ }^{11}$

In his novel Blade among the boys (1962), Nzekwu incorporates and amalgamates themes on which he had touched in Wand of noble wood with others in a more detailed study of the turbulent confluence of Roman Catholicism and Igbo traditional religion. Here the meeting of the two streams becomes a maelstrom in which the central character, a young Igbo named Patrick Ikenga, nearly drowns spiritually and morally when both social pressures and attractions of the two faiths place him into the dilemma of training for the Catholic priesthood and the position of okpala, or traditional family priest, after the death of his father. In exploring this personal enigma, which is a microcosmic representation of the larger clash of two religions in a rapidly transforming colonial society, Nzekwu again takes to task foreign missionaries for failing to accommodate indigenous beliefs and practices.

11 Ogbu U. Kalu, "Color and conversion: the white missionary factor in the Christianization of Igboland, 1857-1967”, Missiology: An International Review, 18(1) (January 1990), pp. 61-74. 
The protagonist has much in common with the author, although the extent to which Blade among the boys is autobiographical is not readily ascertained. Like Nzekwu, Ikenga is an Igbo born away from the tribal stronghold in south-eastern Nigeria, namely at Kafanchan in the Hausadominated north. This fictional character enters the world at that railway junction in 1927, a year before Nzekwu's own birth. The fact that the place is a crossroads of tribes and civilisations is in itself symbolic and pertinent to the larger theme of religious conflict. Nzekwu emphasises that at Kafanchan

there were Fulani, Hausa, Ibo, Yoruba, Tiv, Itsekiri, Efik, Ibibio and their sub-tribes. Religious groups already established there included the Church Missionary Society, the Roman Catholic, the Sudan Interior Mission, the St Paul's African Church, the Faith Tabernacle, the Jehovah [sic] Witness[es], and, of course, Islam (p. 10).

In terms of both tribal and religious pluralism, in other words, Kafanchan, is nearly Nigeria in miniature - at least on the surface. Through the eyes of the young Patrick, social harmony nevertheless prevails amongst these religious and ethnic factions that employment on the railway has temporarily thrown together:

He was yet to learn that the membership of each of these groups lived peacefully together because the distance from their home towns had developed in them a sense of oneness (p. 10).

Beneath the veneer of tranquillity in polyglot Kafanchan, however, intrusive discord prevails and even pits child against child, not least in terms of Protestant and Roman Catholic youths unwittingly continuing centuries-old religious battles imported from Europe. Their mutual recriminations and taunting are childish reflections of their parents' clashes:

Roman Catholics would not, for example, patronize bazaars organized by other churches, nor would they enter Protestant church buildings under any circumstances, not even when their friends died and a funeral was on (p. 13).

Meanwhile, Nzekwu insists, Christians in Kafanchan from the Southern Provinces "lived very peacefully with the hill tribe 'pagans', and the Hausas and Fulani Moslems", while maintaining religious tensions in their own ranks (p. 13). This foresages the pivotal theme of missionary Christianity as a disruptive element that runs like a scarlet thread 
through the plot of Blade among the boys as Patrick strives for spiritual maturity despite pressures that compel him to run the gauntlet between the disharmonious demands of Roman Catholicism on the one hand and those of his ancestral religion on the other.

The cast of central characters neatly embodies much of the spectrum of responses to missionary Catholicism that has brought the gospel to the Igbos since late in the nineteenth century. On the surface, at least, Patrick's parents, John and Veronica Ikenga, are devout Catholics, particularly the latter, who is

chairman of the St. Mary's Women's Society to which every married woman belonged; a member of the Legion of Mary; and President of the Christian Women's Association (p. 8).

Given this explicitly religious factor in his family of origin, Patrick becomes an altar boy at seven and finds himself fascinated by the Latin Mass and other trappings of Roman Catholic worship and piety. Upon witnessing a confirmation when apparently not yet ten years of age, the lad expresses to his parents his desire to become a priest and takes confidence in their affirmation of his pre-pubescent sense of vocation (p. 10). A fissure soon emerges in the foundation of familial solidarity, however. In December 1937, only a fortnight before his unexpected death, John Ikenga begins to express misgivings about his son's priestly ambitions. His opposition springs from his conviction of the necessity of maintaining the family line. In a tense conversation with his wife, he insists that he should not allow the devil to instil in him opposition to clerical vocations but adds,

It is unwise to let our only son become a celibate. You should be desirous of having grandchildren to ensure that our names live after we are gone (p. 16).

Shortly after the death of his father, the bereaved Patrick and his mother move to the village of Ado near the important Igbo town of Enugu, a rural locale where decades of Catholic missionary endeavours have failed to uproot tribal spiritual traditions. Emblematic of these, mother and son are immediately thrust into eight days of funeral rituals. The second seed in Patrick's dicotyledonous religious makeup thereby begins to germinate. "He enjoyed every minute of the funeral as long as it lasted", reveals Nzekwu of the bereaved youth's tractable mind. 
While the funeral according to Christian rites forced him to concentrate his mind on the hopelessness of the future without his father, the traditional system took his mind away from his loss, diverted it to other interesting things and made him forget his predicament (pp. 18-19).

At this critical early juncture of his narrative, Nzekwu introduces Patrick's uncle, Ononye, to represent intransigent adherence to traditional Igbo religion. When Patrick falls ill with malaria, his local kinsmen attempt to cure him through sacrifices to their ancestors, talismans, and the services of an herbalist. His mother, with the endorsement of a few like-minded villagers, appeals to her brother-in-law for permission to take the youth to a hospital. Ononye, who has been elected to serve as a sort of regent okpala until Patrick attains his majority, and other members of the old guard refuse, however. Nzekwu uses this incident to juxtapose two fundamentally different emergent mindsets amongst the Igbos during the 1930s:

It was significant that all those who suggested taking Patrick to the hospital had had education at mission schools where they learnt (who cared very much about practice?) the rudiments of Christianity and had been baptized (p. 23).

Rather than using this opportunity to argue in favour of the secular benefits of missions, however, Nzekwu exploits it to illustrate how many Igbos have taken advantage of missionary endeavours to advance their own worldly agendas. He frames his perception of their responses to Christian proclamation in terms of a categorical indictment:

But while the mission authorities looked upon education as a useful guide to baptism, synonymous with conversion, the converts regarded attendance at church services and catechism classes and baptism as conditions they must fulfil if the mission authorities were to teach them the three R's, their primary objective. In other words, the quest for education had made necessary their accepting the Christian faith. Their desire to demonstrate that they belonged to the new generation of literate gentlemen had made them attend the hospitals, a byproduct of Christianity, and speak to Ononye words of wisdom in which they themselves had little faith, for the old order still had a firm grip on them (p. 23).

The young Patrick is already cognizant that the perception of the Catholic priests at Kafanchan of his pious parents as model Christians differed from what he knew of his father. Again, Nzekwu casts aside all subtlety in describing the limits of popular orthodoxy and orthopraxis: 
Had the priests gone behind the scenes[,] they would have discovered that neither John Ikenga's brand of Christianity, nor those of many others he knew, was the model they preached each Sunday from the altar. They could have discovered for themselves the numerous charms John Ikenga hid behind photographs hanging on the walls of their parlour. His was quite a different brand of Christianity - a Christianity that allowed for the limitations of his upbringing in traditional surroundings, a Christianity that accommodated some principles and practices of his tribal religion. For one thing, he never could drop the primary aim of tribal worship: to reinforce life by means of prayers, sacrifices and sympathetic magic (p. 29).

Only much later in the narrative, as we shall see, does Nzekwu reveal unambiguously that Veronica Ikenga, despite much initial evidence to the contrary, is also ultimately captive to a pivotal Igbo belief.

After his recovery in March 1938, Patrick is placed in the custody of an uncle, Andrew Ikenga, a lapsed Roman Catholic in Zaria. This relative's concubine makes life miserable for the youth whose presence she clearly resents, both before and after the three move to Kano, and even physically abuses him to the point that he must be briefly hospitalised. His uncle proves to be authoritarian, insisting that he unnecessarily repeat standards at school. Patrick nevertheless presses ahead in his faith, and on his own initiative he receives the sacrament of confirmation. His daily piety and continuing desire to enter the Catholic priesthood earns him the derision of his uncle's mistress, who mocks him and convinces the neighbours in their compound to call him "Father Patrick". His spiritual mettle having passed this early test, the pious youth returns to Ado to complete his primary education in the hope of being admitted to Holy Trinity College after standard six. Nzekwu's authorial intrusion as Patrick boards a train en route to Ado again emphasises the relative poverty of a morally debased missionary Christianity when confronted by a deeply entrenched Igbo religion:

Had he known it he was coming home to a situation that was going to test his Christian faith severely. He was returning to become another target over which indigenous traditional religion, which time alone had equipped with a powerful influence in all spheres of life, battled with Christianity, imported only less than a century before, with its army of missionaries whose weapons - philanthropism and entreaty — had been discarded for compulsion and indifference (p. 42).

Patrick's entry into adolescence and his return to Ado herald a period in which his introduction to the ways of his forefathers is accelerated. 
His uncle Ononye stresses the gravity of such religio-cultural maintenance in the face of what he perceives as a dangerous incursion of foreign religion and expresses his determination to resist the latter as a threat to Igbo identity:

"These children," Ononye commented, turning round on his seat, "are the links that will carry our traditions, which distinguish us from all other peoples, to future generations. If, because the school authorities 'put the water of God' on them, they fail to take part in our rituals, time will come when when we can no longer identify one man from another. And if, as we do believe, the dead do see and have power, I will be one of those who will rise from the dead to take revenge on those who let our traditions die away" (pp. 52-53).

At the feet of this determined uncle, Patrick is taught "a litany of the ancestral spirits of the Ikenga lineage" (p. 49) and also learns about $i y i$, or cultic emblems of various gods, and aja, or sacrifices made to ward off evil spirits. Such customs as the pouring of libations and breaking of cola nut also come to the fore. Adhering to a prevalent custom of early postcolonial Nigerian fiction, Nzekwu dwells on these and other elements of the youth's education to insert relatively detailed didactic sections into his text, presumably with non-Igbo readers in mind. Within the context of the plot, they serve to underscore the depth of abiding devotion to tribal tradition still prevalent amongst the Igbo during the 1940s, notwithstanding decades of Roman Catholic and other missionary endeavours. Still faithful to his vision of becoming a Catholic priest, Patrick hears a student from Holy Trinity College seek to bridge the cleft by voicing the commonly heard argument that beneath a veneer of religious differences the two faiths in question are quite similar, not least with regard to mutual emphasis on monotheism. "He is the one we all worship", asserts this student.

The only difference is that in the Church our prayers are directed to Him through foreign saints but here we approach Him through our ancestors who are our own saints (p. 51).

Yet nothing evolves on this arguably infirm foundation of religious commonality.

Patrick's preparation to become the family okpala places his devout Catholic mother Veronica into an awkward dilemma. On the one hand, she accepts the tribal practice of having such a titular head of the family and understands that it is her son's lot to accede to that position. Ve- 
ronica wishes that the position could somehow be divided, an impossibility given the pervasive nature of tribal religion in traditional life generally. Nzekwu spells out her stance explicitly:

In Mrs Veronica Ikenga's opinion there was nothing wrong with the political, social and judicial functions attached to the headship ... What she hated were the religious duties that lineage heads were called upon to perform.

Her hostility to them proceeds directly from Biblical teaching: "These functions were anti-Christian; they went against the first commandment. That was why she hated the office" (p. 81). Yet she holds her peace and never expresses to Patrick her opposition to what she apparently perceives as his inexorable progress towards permanent ensnarement in tradition.

Having set his protagonist on this path, Nzekwu proceeds to lambast the educational endeavours of Catholic missionaries by exploring Patrick's encounter with it. Indeed, much of the last 100 pages of Blade among the boys is given to this critique. Nzekwu first returns to the theme of sectarian narrow-mindedness by sending Patrick to the Catholic Mission Central School, where the young pupil encounters a stock character in the headmaster, Father O'Brien. This divine exploits the relative dearth of educational institutions in the area to inveigle children to convert. Mounting a table outdoors after a large number of prospective pupils gather in the hope of enrolling, he segregates the children according to their religious affiliation and announces,

You non-Catholics ... you'll go and try other schools in town. We have a very limited number of places, so I am not going to consider any of you for admission. If however you are keen on coming to this school, then become a Catholic and come back for admission next year (p. 84).

Patrick clears the denominational bar, but his ongoing de facto detachment to the folkways of the Igbos continue to create tension for him. Only a fortnight after his admission to Catholic Mission Central School, he performs with other young musicians at a traditional funeral, thus arousing the ire of Father O'Brien, who warns his charges against participation in "idolatrous" rituals. To Patrick, such criticism seems exaggerated. He argues in vain to the headmaster that the only idolatrous rituals involved had been performed before he and his colleagues arrived to play. His presentation of his case only earns him a beating. 
This incident sets up a pivotal if implausible dialogue in which Ononye lectures his chastised nephew on the incompatibility of Igbo traditional religion and Catholicism before haranguing him on the shortcomings of missionary strategy. The alien purveyors of the gospel, he laments, have been condescending and ignorant. Consequently, Ononye complains,

Christianity and our traditional way of life have been in conflict right from the very first day her missionaries stepped on our soil. The Christian missionaries hve always criticized our customs and called us "bush men." They have called us "pagans" and "heathens", words which I am told mean people without a religion.

Such appellations were patently ridiculous, he tells his nephew:

Yet in the few months you have been home you have seen and heard enough to realize that we do have a religion.

He allows that the first missionaries in the area were "very nice people" but insists that the Igbos actually "found them and their sermons unattractive and boring". Whether Ononye is here relating his own experience or conveying oral tradition is unclear. In any case, he declares categorically that the Igbos attended Mass or other missionary functions only because

at the end of each religious service or lecture, they distributed dresses, bottles of kerosene, heads of tobacco and items of household use to us (p. 86).

What particularly irks Ononye, given his concern about the future viability of Igbo traditions, is the missionary practice of focusing on African children as a means of gaining a bridgehead for the church. He accuses foreign missionaries of subterfuge in this regard. Unable to win the older generation to Christianity,

[T]hey decided to turn their attention to our children, who were yet unformed and pliable, and who would be the fathers of tomorrow. They introduced schools and made them a cover under which Christianity would operate.

No less seriously, the missionaries had exploited health ministry as a means of propagating their "foreign faith":

As soon as the mission hospitals were built[,] even those institutions became a means of spreading the faith. Patients, as long as they could 
walk, were made to attend religious services morning and evening (pp. 86-87).

Apparently believing that Christianity and traditional Igbo religion and culture generally were nevertheless to some extent compatible, Ononye regrets that no via media was found between wholesale indictment of the latter on the one hand and full embracing of it on the other. Without specifying which elements he believes missionaries ultimately could have found acceptable, he laments that

they sought to change our whole way of living and in its place to create such conditions as existed in their own country and conducive to the spread of their faith.

Nzekwu then offers general missiological advice through Ononye:

I must say it was noble of those who initiated such humanitarian policies and institutions as are those of the Christians! But I maintain that unless their agents have common sense enough to realize that Christianity has to be modified to make it acceptable to us they will make no true converts (p. 87).

In this diatribe Ononye does not specify how such contextualisation should proceed. Before the end of the same chapter, however, Nzekwu suggests that it could begin on the liturgical front. When an indigenous teacher named Ndibe teaches a Christmas carol in Latin, Patrick, who several years earlier was fascinated by the Mass, now has the audacity to question the appropriateness of learning a song which neither he nor his classmates can understand. Perceived as a challenge to authority, this effrontery earns him a caning. Amazingly enough, Patrick's desire to train for the Roman Catholic priesthood survives this episode (pp. 89-90). Notwithstanding Ononye's unsubstantiated generalisations about the insincerity of Igbo conversions to Christianity that reflect nothing more than a desire to reap whatever material benefits may result from them, his piety and sense of vocation remain essentially intact.

Patrick's enrolment at Holy Trinity College, under the supervision of Father Matthews, gives Nzekwu another major opportunity to vent his criticism of Catholic missionary education. At this "successful institution", graduation from which is "a passport to employment anywhere in the country", hypocrisy compounds sectarian narrowmindedness. Admission is restricted to Roman Catholics, but "it was known that, in the football class, boys from various Christian denomi- 
nations could be found" (pp. 99-100). Patrick discovers consistency in religious authoritarianism; Nzekwu illustrates this initially through authorial comment:
Apart from such direct orders that students must always reflect in their attitudes their Christian upbringing, there were such subtle measures as the transfer of essay writing from a weekday to imme- diately after Mass on Sunday morning in the college chapel. On Friday studies were suspended, as one by one the classes in the school were called out for Confession. Whether they wanted it or not, on Friday all students had to go to Confession for fear of exposing themselves to sarcastic remarks and punishment from the priests (p. 100).

When Patrick breaks tradition by challenging the staff about these techniques, he is branded a potential agitator who must be watched, even though the youth explains that he desires to become not a priest who relies on compulsion but rather one who can "defend my faith and justify the methods adopted for its spread; at least, among my own people". Nzekwu inserts indirect discourse to reflect the defensive reaction of the priests: "Who would want such an inquisitive nigger for a brother cleric? Could you think of a monkey claiming to teach you how to be human?" (pp. 102-103). Whether the missionary educators in question actually express such unabashedly racist attitudes is unclear. Quite unambiguous, however, is the reaction of Father Gerard, the lecturer in Latin, who upbraids Patrick for failing to fill a thirty-page copybook with repetitions of the Pater noster in Latin.

"Shut your trap, your liar", the priest hissed through tightly locked teeth, advancing menacingly towards him... "This is the last time you'll ever lie to me," he added, swinging the boy a blow (p. 105).

The incident leads to Patrick's expulsion from Holy Trinity College. Nevertheless, this would-be priest is determined to soldier on, believing that

it was only from within the fold that he could fight effectively the coercive measures used by clerics and other church officials in the spread of the faith among his people (p. 109).

He never receives a chance. Unable in the short term to gain admission to any other school, Patrick accepts a traineeship with the railway, a post which, to his dismay, his uncle Andrew has arranged with a bribe. Urbanisation and concomitant freedom from both the tribal 
and missionary religious strictures of village life eventually take their toll. In Lagos, Patrick remains pious only briefly before dropping mealtime prayers, participation in Confession, and attendance at Mass in favour of dancing lessons and other worldly pastimes. In the turbulent political climate of the late 1950s, he hears embittered advocates of Nigerian independence rail against the "unholy trinity" of missionaries, trading firms, and the colonial government collaborating to maintain British hegemony. Nzekwu's voice speaks through those of these protestors:

They criticized the missionaries for their outight condemnation of the way of living of all African peoples in their attempt to set up new social conditions which would favour the spread of Christianity. They lamented the loss, in parts of Africa, of traditional works of music and of dances owing to the missionaries preaching against them because they were connected with tribal religion. They lamented the false front Christian churches were putting up in the race hatred which was being practised by the whites in South Africa (p. 124).

These influences continue to take their moral toll. After completing his period of training in Lagos, Patrick is posted to Umuahia near Port Harcourt, where he abandons his celibacy in favour of sexual promiscuity, begins to take bribes, and builds a large house. His ethical decline and pursuit of the bourgeois life, in other words, mirror the course that many other formally educated Nigerians take on the eve of independence. In his spiritual anomie, however, Patrick experiences the renaissance of his desire to become a Catholic priest. This goal is further complicated by his romantic involvement with Nkiru, a teenaged girl who aspires to a career in education. After a decade of self-imposed excommunication, Patrick again partakes of the Eucharist and gains admission to a seminary over the eleventh-hour protestations of his relatives who still want him to become their okpala. Even his devoutly Catholic mother reveals the depth of her residual debt to tribal religion when she attempts to persuade him to abandon his priestly ambitions. Veronica informs her one child,

Since you have chosen to become a priest without my permission, since you have decided to waste your life for nothing, since you have decided to resist me, to make your relations the laughing-stock of the people of Ado, know that you no longer have me for your mother. I myself know that I no longer have a son (p. 166). 
She dies shortly thereafter. At the behest of his bishop, Patrick attempts to restore familial harmony in Ado, but the relatives of this seminarian meet him with an ultimatum: become an okpala or stay away. He chooses the latter course, thereby making permanent the rift separating him from both his family and their faith.

The enamoured and still virginal Nkiru also refuses to accept $\mathrm{Pa}-$ trick's decision to continue on his path towards ordination and clerical celibacy. Demonstrating the power of traditional healing, she gives him an aphrodisiac secured from a tribal herbalist and uses it to seduce him, falling pregnant in the process. Upon learning of her condition, an educational administrator dismisses her, and Patrick's bishop orders him to leave the seminary. Blade among the boys thus ends with the intellectually semi-developed and spiritually still longing protagonist alienated from both wings of the spiritual life in which he has been nurtured without attaining fulfilment in either one. Suggested is Nzekwu's belief that this represents a common pattern of relegation to the religious no man's land of postcolonial Nigeria.

When assayed with the touchstones of conventional literary criticism of virtually any school, Blade among the boys smacks of being the work of a neophyte novelist whose zeal in arguing his case vastly exceeded his talents as an artist. Most of the characters are weakly developed and one-dimensional, never rising above the level of functional voices to become credible human beings. Patrick Ikenga and, to a lesser extent, his mother Veronica are more richly countered exceptions who, however, stand as exceptions to their counterparts who prove the rule. Nzekwu's prose, moreover, is generally flat and fails to evince any particular artistic creativity.

In his scathing indictment of Nigerian novelists in general, especially the foundational generation of Chinua Achebe who published extensively during the euphoric post-independence years of the 1960s, A mask dancing, Adewale Maja-Pearce took to task those writers for their alleged fixation on cultural defensiveness as they had spent much of their artistic creativity on endlessly describing the impact of British imperialism and concomitant cultural-religious hegemony on indigenous cultures and beliefs. To Maja-Pearce, it seemed particularly ironic that most of these critics of modernity had elected to write in English, "the language of the modern world par excellence", in vilify- 
ing the deleterious impact of what had been inflicted on Nigeria through that language. As one of his many targets, he focused on the renowned Chinua Achebe's insistence on the reality and potency of Igbo deities in such well-known novels as Things fall apart. ${ }^{12}$

Nzekwu is one of the novelists at whom Maja-Pearce does not aim his critical rapier. This is understandable when one considers that unlike many of his contemporary counterparts, Nzekwu does not attempt to establish the reality of the tribal gods. He is content to suggest that for his representative protagonist, Igbo traditional religion seems at times to speak more directly than Christianity, at least before Patrick discovers at the time of his initiation at Ado that the local jujus are no more divine than he. Again, this underscores the dilemma of the young Nigerian Roman Catholic who eventually cannot believe wholeheartedly in either his tribal gods or the ostensibly imperialist religion of Christianity.

All of that said, one can nevertheless argue that Blade among the boys merits greater scholarly attention than it has ever received, perhaps not least by missiologists and others who are interested in eye-witness accounts of the impact of Christianity on Igbo society and the dilemma this posed for formally educated youths who are caught in a web of conflicting spiritual loyalties and subjected to pressures on the side of both missionary Christianity and tribal religion. To be sure, Nzekwu's black and white mode of expression, caricature of Roman Catholic missionaries, and ridiculing of the motives of Igbo converts to Christianity all detract from the verisimilitude of his narrative and may lead readers with a more sophisticated knowledge of the proliferation of Christianity in Nigeria to discount the value of Blade among the boys as a light unto the path of missiological enquiry. Allowing for the neophyte author's artistic licence and lack of finesse with the pen, however, one can glean from Blade among the boys a provocative account of the consequences of the failure of missionaries to present a culturally contextualised gospel. Equipped with greater sensitivity to indigenous culture, Nzekwu argues, they could have ameliorated the tensions in which their con-

12 Adewale Maja-Pearce, A mask dancing: Nigerian novelists of the Eighties (London: Hans Zell Publishers, 1992), pp. 10-22, 171. A useful study in defence of Achebe is Kalu Ogbaa, Gods, oracles and divination: folkways in Chinua Achebe's novels (Trenton: Africa World Press, 1992). 
verts found themselves and aroused less hostility from defenders of Igbo traditions. On the other hand, Nzekwu fails his readers by opening the door for a discussion of, but never entering into, the opportunities which this monumental missionary blunder gave for the emergence of the indigenous churches, whose prominence on the increasingly variegated religious landscape of Nigeria waxed from decade to decade during the twentieth century.

Furthermore, Nzekwu's dismissive attitude towards the sincerity of conversions to Christianity is itself suspect. His declarations about Igbos nominally accepting the gospel in order to gain admission to schools and other benefits is contradicted by the faith of Patrick Ikenga and his devout mother. Nzekwu's quite correctly underscores the continuing rôle of traditional religious beliefs and practices amongst Igbo churchgoers, but his indictments of Igbo Christians as insincere in their conversions remain unsubstantiated assertions. An enormous burden of proof rests on the shoulders of any writer of either fiction or nonfiction who insists that people insincerely go through the motions of receiving Christianity, and Nzekwu does not begin to prove his case. His observations concerning the remnants of traditional religious devotion do not disprove the genuineness of conversion; they merely underscore the fact, which can be seen at many points where people convert from religion to another, that people rarely undergo total spiritual transformations overnight.

Keywords

Christianity in Africa

Conversion

Onuora Nzekwu
Trefwoorde

Christendom in Afrika

Bekering

Onuora Nzekwu 